\title{
Aspectos do Pós-Positivismo e a Crise da Legalidade
}

\author{
ISAC PENEDO PINTO \\ Acadêmico de Direito da Universidade Federal do Espírito Santo (UFES), Monitor da Disciplina \\ Teoria do Estado, tendo exercido, anteriormente, Monitoria na Disciplina Introdução ao Estu- \\ do de Direito I, ambas sob a Orientação do Professor Dr. Angel Rafael Mariño Castellanos, \\ Ex-Membro do Centro Acadêmico Roberto Lyra Filho (CARLF), Ex-Integrante Voluntário do Pro- \\ grama de Extensão Universitária, Projeto Resgate, Subprojeto do Balcão de Direitos da Secre- \\ taria Especial de Direitos Humanos do Governo Federal (SEDH). Atuou, também, no Cartório \\ de Feitos da Fazenda Pública Municipal de Vitória e no Banco do Desenvolvimento do Espírito \\ Santo S/A, na Gerência de Acompanhamento de Projetos, Setor Corporativo, ambos como \\ Estagiário. Atualmente, é Estagiário do Escritório Azevedo Sette Advogados, em Vitória/ES.
}

Submissão: 15.04 .2011

Parece 1: 26.08.2011

Parecer 2: 26.08.2011

Decisão Editorial: 26.08.2011

RESUMO: 0 presente estudo tem como objetivo principal refletir sobre as faces e os aspectos do pós-positivismo e alertar para a crise de legalidade que assola a sociedade brasileira na atualidade. Pretende-se evidenciar que ambos os temas, longe de andarem por vias distintas, seguem de mãos dadas um mesmo itinerário. Negar um ou outro é negar o próprio Direito renascido das cinzas e dos monturos da Segunda Grande Guerra.

PALAVRAS-CHAVE: Teoria do Direito; pós-positivismo; legalidade.

ABSTRACT: The present study aims mainly to reflect on the faces and aspects of post-positivism and alert about the legality crisis plaguing the Brazilian society today. It is intended to show that both subjects, far to walk by distinct pathways, go hand in hand the same itinerary. Denying one or another is to deny the law itself reborn from the ashes and middens of the Second World War.

KEYWORDS: Jurisprudence; post-positivism; legality.

SUMÁRIO: Introdução; 1 Parte I: para sempre pós-positivismo; 1.1 Breve nota histórico-filosófica; 1.20 pós-positivismo; 1.30 Direito sob a nova perspectiva; 1.4 Mudança de papéis no cenário jurídico; 1.5 Sobre princípios e regras; 1.6 Desenvolvimento judicial; 1.7 Direitos fundamentais: a grande personagem do pós-positivismo; 1.8 Reflexões; 2 Parte II: A crise da legalidade; 2.1 A crise; 3 Jurisprudência; 4 À guisa de conclusão: um itinerário sem volta; Referências.

\section{INTRODUÇÃO}

É universalmente conhecido no meio jurídico que, logo após as agruras e os assombros da "Era das Catástrofes", a partir da década de 1950 do século passado, o pensamento jurídico navegou das agitadas e tormentosas 
águas do positivismo lógico-normativista para as águas perenes e tranquilas do pós-positivismo.

Desde então, muita coisa foi suprimida, alterada, acrescentada e repensada, sempre tendendo para um universo jurídico subserviente aos valores consagrados pela sociedade - mormente a justiça e a dignidade da pessoa humana -, ainda abalada por duas guerras devastadoras.

Nada obstante tantos avanços tão arduamente granjeados, percebe-se, ainda hoje, em pleno século XXI, um clima de receio, de cautela e, até mesmo, de rejeição à maré valorativa característica do pós-positivismo. De fato, não poucos Magistrados, advogados e outros operadores do Direito; acadêmicos e teóricos ainda ancorados no tradicionalismo jurídico, mantêm-se fixos em preceitos e ensinamentos anacrônicos, já superados pela doutrina dos dois últimos quartéis da centúria passada e, o que é por demais importante, pela jurisprudência dos Tribunais Superiores. Ainda teimam em ensinar e defender com unhas e dentes aquela teoria pura na qual a tônica era a rígida separação entre Direito e moral e todas as suas repercussões na concreção daquele, o que cerceia o alcance e o desenvolvimento do próprio pós-positivismo, incidindo nas teorias e teses que o constituem. Talvez seja receio de subordinar o Direito, uma ciência social autônoma, a outras áreas do conhecimento como a filosofia, a sociologia e a ciência política, ou, então, haja medo de que a cientificidade que lhe é inerente se perca. Cada um tem suas razões. Mas a questão é: ainda falta em muitos a segurança para aceitar o inevitável.

Por outro lado, deixar-se levar pela embriaguez valorativa é um erro que está constantemente conspurcando a ordem jurídica e parece ter, assustadoramente, contagiado a muitos. Entre as mais infelizes decorrências desta embriaguez está a falta de cultura da legalidade.

A lei é vista, paradoxalmente, como um dos grandes vilões do desenvolvimento judicial. Ao passar por cima da lei, pensam estar fazendo um favor ao Estado, à sociedade e ao próprio Direito. Ledo engano que muitas vezes leva ao desastre jurídico, à falta de identidade do campo jurídico e, o que é pior, à falta de segurança jurídica.

O presente artigo tem como objetivos (1) dissertar sobre alguns aspectos do pós-positivismo; (2) refletir acerca da cultura da falta da legalidade; (3) sinalizar para as consequências de tal costume; e, por fim, (4) relacionar os temas, esclarecendo alguns pontos que podem parecer controversos.

Para tanto, dividiu-se o desenvolvimento do artigo em duas partes: a primeira apresenta e debate o tema do pós-positivismo e algumas questões 
relevantes sobre o assunto; e, amparada na primeira parte, na posterior pretende-se brevemente refletir acerca da crise da legalidade que assola o País.

\section{PARTE I: PARA SEMPRE PÓS-POSITIVISMO}

\subsection{Breve NOTA hISTÓRICO-FILOSÓFICA}

A história da filosofia do Direito é, sobretudo, a história de uma dicotomia. Se fosse possível, seria comparada a um pêndulo, e isto porquanto talvez a característica mais marcante da história do Direito seja a questão da sua fundamentação, manifesta sob o pano de fundo da dualidade entre direito natural/direito positivo.

No princípio, havia aqueles que, a despeito de algumas divergências internas e particulares, acreditavam em um direito natural. Um direito que era superior e supremo, ao qual o direito dos homens devia se conformar sob pena de não ser considerado legítimo. Era um Direito vinculado estreitamente com a moral e com os valores, os quais eram originados na práxis. Havia outros que desmentiam a existência de um direito universal, eterno, imutável, superior ao direito humano, e consideravam o direito posto pelos governantes o único direito legítimo. Os primeiros foram conhecidos como socráticos e os últimos, sofistas. A arena da disputa era a sofisticada e tão cultural Atenas. Foi assim que a dicotomia teve início, sobrevivendo às intempéries do tempo, alcançando, ainda que de forma atenuada, os dias de hoje. Por muito tempo, sofistas e socráticos disputavam quem estava revestido de razão. Pela quantidade de adeptos, influência e notoriedade deles, a ideia do direito natural fundamentado na práxis prevaleceu.

Era o início do império do direito natural, que daria lugar no trono da fundamentação do Direito somente no século XIX para seu rival, o direito positivo.

Posteriormente, já na época dos romanos, Cícero foi o grande defensor do direito natural, enquanto os que levavam a bandeira da lei posta eram os epicúreos. E assim, as discussões avançaram até que, na aurora do milênio cristão, o outrora pomposo Império Romano ruiu e a população espalhou-se: era o início das trevas e daquele famoso feudalismo, que iria viger, efetivamente, até a vitoriosa Revolução Francesa.

Nos tempos medievais, a dicotomia manteve-se. Foram tempos nos quais a religiosidade impregnava o cotidiano da população, a cultura, os costumes e, inevitavelmente, o Direito. Permaneceu a rivalidade direito natural versus direito dos homens, com uma mudança: a autoridade epistemo- 
lógica do direito natural era a Autoridade Divina, que punha aqueles valores universais e imutáveis na razão humana. O pluralismo tomou forma, sendo que diversas ordens jurídicas coordenavam a população esparsa. Por conseguinte, o poder político e jurídico era bastante diluído, predominando o poderio judicial da Igreja, até aproximadamente os séculos XII-XIII, período no qual o poder passou a centralizar-se nos senhores feudais. No correr do chronos, o sol começava a erguer-se no horizonte do mundo.

Novos tempos foram aqueles, ditados pelo surgimento de novas ideias, muitas vezes conflitantes com os dogmas católicos e que refletiram na cultura, nas ciências e na política. O homem passa a ser o centro das atenções de todo o conhecimento, a Igreja se divide em Católicos e Protestantes, o Estado moderno começa a ser delineado e fundamentado e, para coroar esse novo tempo, surge uma nova classe social, vinculada ao comércio e às atividades mercantis: os burgueses. Nas aparências, a dualidade permanece, com um detalhe: o direito natural não encontra na divindade sua autoridade epistemológica, mas, sim, na razão do homem. Ora, em vias de antropologização da cultura, nada mais óbvio que houvesse antropologização no Direito. Era a época da racionalidade. Foi em busca de um poder racional que os teóricos do Estado defenderam um poder soberano, uno, mas limitado, separado completamente da religião. E foi em busca de um Direito que expressasse esta avalanche racional, marcadamente lógica, que os jusracionalistas defendiam a codificação daquele direito eterno, imutável e valorativo. Foi a ruína do direito natural.

No século XIX, as revoluções liberais do século que se passou mudaram as estruturas e os fundamentos do Estado moderno e também do Direito. Do Estado absoluto passou-se ao Estado liberal. Do direito natural passou-se ao direito positivo. Foi um século cientificamente efervescente. A face do Direito mudou: não havia outro direito senão a lei. Esta seria a única fonte do Direito. A ideia de lei natural, conformando a lei do homem, virou passado. No âmbito metodológico, a neutralidade do Magistrado perante a lei tornou-se um dos pontos principais dos ditos positivistas jurídicos. $\mathrm{O}$ único Direito, o Direito legítimo, era o Direito posto pelo Estado. Tudo em função da racionalidade. Foi um tumulto para a ciência do Direito quando Julius Herman von Kirchmann proferiu em uma palestra a famosa frase: "Bastariam três palavras retificadoras do legislador para que bibliotecas jurídicas inteiras fiquem reduzidas a papel de refugo" ${ }^{\prime \prime}$. Era a crise do Direito: a aparente perda da sua cientificidade. E esta crise durou desde meados do século do Código de Napoleão até o segundo quartel do novo século, quando

1 REALE, Miguel. Lições preliminares de direito. 27. ed. São Paulo: Saraiva, 2006. p. 325. 
um professor austríaco de Direito, judeu e amante da lógica e das ciências exatas, tirou o Direito daquele "charco de lodo", firmando-o na rocha da normatividade e autonomia científica ao publicar um livro que iria mudar a face da ciência do Direito. O ano era 1934, o livro se intitulava Teoria pura do direito e o professor, Hans Kelsen. A ideia era clara: o Direito é marcadamente normativo, sendo a norma o objeto de estudo do jurista que devia manter-se neutro e afastado de quaisquer áreas do conhecimento que não o Direito. A autonomia do Direito, para Kelsen, só se alcança isolando o jurídico do não jurídico. Isso quer dizer que o Direito, como ciência, deve significar um estudo lógico-estrutural, seja da norma jurídica, seja do sistema jurídico de normas. A ciência jurídica, dizia Kelsen, é uma ciência autônoma, que se presta a estudar somente a norma jurídica em suas estruturas, jamais no seu conteúdo. Ademais, as únicas coincidências que o Direito tem com a moral é que ambos controlam a conduta humana e ambos são sistemas normativos ${ }^{2}$. De resto, de nada serviam a moral, a ética e a justiça para a seara jurídica, pelo simples fato de que a ciência jurídica era limpa, pura, sem nenhuma intervenção daqueles outros sistemas. Infelizmente, a extrema formalidade daquela teoria pura deu ensejo a governos autoritários, como foi o caso da Alemanha nazista, a Itália fascista e a Rússia stalinista, o que desencadeou a guerra mais desastrosa que o mundo inteiro presenciou: a Segunda Guerra Mundial. O repúdio à conduta nazista, revestida de preconceitos e racismos, tornou-se ainda pior quando se observou que aquele Direito, imbricado com a teoria pura, legitimou ordens cruéis e desumanas.

Foi a Escola de Baden que reuniu pensadores que levaram a cabo a superação da neutralidade do cientista jurídico perante o direito positivo. Ressuscitam-se as ideias kantianas, ensejando uma reflexão crítica acerca do Texto Legal, tendo como crivo a dignidade humana. Supera-se, assim, a ideia de que um jurista, ao estudar a lei, deve manter-se neutro. Entre os juristas desta escola cabe considerar os pensamentos de Gustav Radbruch e Emil Lask, os quais deram subsídios para entrada de novos tempos.

\subsection{Pós-Positilismo}

É indubitável, como visto, que o pós-positivismo é uma construção relativamente recente, não datando nem 70 anos. Entretanto, devido a diversos fatores, em poucos momentos da sua história o Direito desenvolveu-se vertiginosamente e em áreas específicas, gerando um boom doutrinário e jurisprudencial, seguindo uma linha axiológica inédita.

2 KELSEN, Hans. Teoria pura do direito. 6. ed. São Paulo: Martins Fontes, 2000. p. 67. 
Por pós-positivismo ${ }^{3}$ entende-se o rótulo que abriga um conjunto de abordagens teóricas, ideológicas e metodológicas que incidem no Direito, tendendo para a realização e a concretização de valores e princípios por meio do Direito posto pelo Estado; é a busca por uma conciliação entre dois dos mais caros princípios ${ }^{4}$ para a ordem jurídica: a Justiça e a segurança jurídica. Por muito tempo, como foi visto, essa questão foi um grande entrave para os juristas e Magistrados. Por vezes, sobrepunha-se a ideia de que a segurança devia prevalecer sobre a justiça; em outras, a batalha era ganha pela justiça. Com o findar da Segunda Grande Guerra, cujas atrocidades à humanidade foram ensejadas por um normativismo cego e inescrupuloso, os teóricos voltaram-se para confeccionar uma ideia de Direito que, não deixando de lado o Texto Legal, primasse pela realização de valores da sociedade e da condição humana. Era uma terceira via entre o direito positivo e o direito natural.

O que ocorre é uma releitura das propostas fundamentais do positivismo jurídico e não uma ruptura radical como às vezes se pensa. Como afirma com propriedade o Professor Luis Roberto Barroso:

Em certo sentido, apresenta-se ele [o pós-positivismo] como uma terceira via entre as concepções positivista e jusnaturalista: não trata com desimportância as demandas do Direito por clareza, certeza e objetividade, mas não o concebe desconectado de uma filosofia moral e de uma filosofia política. ${ }^{5}$

O positivismo não aparece apenas na nomenclatura. Muitas das teorias desenvolvidas no decorrer do pós-positivismo partem de concepções juspositivistas. Dessa forma, cabe deixar claro que o pós-positivismo não elimina por completo as teses do positivismo jurídico ${ }^{6}$ nem as ignora, mas implica uma releitura das tais, principalmente a tese de distinção entre Direito e moral, como se esferas estanques e incomunicáveis fossem.

3 No tocante à nomenclatura, há outras possibilidades - ainda que este artigo utilize-se de "pós-positivismo" -, quais sejam: neopositivismo, neoconstitucionalismo, soft positivism ou positivismo inclusivo.

4 O vocábulo "princípio" aqui usado expressa a estrutura jurídica que, jungida a valores, fundamenta e sustenta o ordenamento jurídico. Tal esclarecimento é necessário, tendo em vista a imperativa coerência dos textos científicos; coerência que tem sido deixada de lado não poucas vezes nos textos jurídicos, sobretudo no que concerne à questão "regras e princípios". Tem-se utilizado esses vocábulos, definindo-os e, no decorrer da dissertação, empregando-os em contextos que não se coadunam com aquela definição. Fere-se, assim, a coerência tão imprescindível para o jus operandi. Ver SILVA, Virgílio Afonso da. Princípios e regras: mitos e equívocos acerca de uma distinção. Revista Latino-Americana de Estados Constitucionais, 1(2003): 612-613.

5 BARROSO, Luis Roberto. Introdução, a reconstrução democrática do direito público no Brasil. In: $A$ reconstrução democrática do direito público no Brasil. Rio de Janeiro/São Paulo/Recife: Renovar, 2007. p. 6-7.

6 CALSAMIGLIA, Albert. Postpositivismo. DOXA - Cuadernos de Filosofía del Derecho, v. 21-I, p. 209-210, 1998. 
Importante notar, também, que o pós-positivismo não é propriamente uma corrente filosófica. Autores como Robert Alexy ${ }^{7}$, Ronald Dworkin ${ }^{8}$, Carlos Santiago Nino ${ }^{9}$, Luigi Ferrajoli ${ }^{10}$, Manuel Atienza ${ }^{11}$, Gustavo Zagrebelsky ${ }^{12}$, entre outros, não são sequazes de uma mesma corrente de pensamento, mas todos são considerados pós-positivistas. É possível perceber em suas teses certas características e tendências coincidentes que constituem uma nova atmosfera teórica, metodológica e ideológica sem que isso os enquadre em uma corrente unitária de pensamento.

O pós-positivismo é, sobretudo, uma nova forma de se pensar o Direito. Deixa para trás todas as teorias baseadas em juízos de fato para se tornar uma ideologia, constituindo um conjunto de juízos de valor acerca de uma determinada realidade. Agrega o melhor do jusnaturalismo, do positivismo e até mesmo do realismo jurídico, superando a vetusta dicotomia positivismo/jusnaturalismo, para tornar o Direito mais flexível, mais humano, mais justo, tencionando suprimir quaisquer possibilidades de validar ordens jurídicas ofensivas aos valores mais caros do homem e da sociedade ${ }^{13}$. Com efeito, percebem-se certas mudanças na caracterização do Direito, quais sejam: (1) é visto sob uma perspectiva mais valorativa, como um sistema aberto axiológico-teleológico; (2) a Constituição se torna a pedra angular de todo o ordenamento jurídico, irradiando seus princípios e conteúdo por todo o sistema, condicionando a atividade dos Poderes do Estado e até as relações privadas; (3) dá-se o fenômeno da normatividade dos princípios que passam, ao lado das regras, a compor o sistema jurídico, tornando-se componentes elementares para a fundamentação do sistema jurídico; (4) a interpretação, a aplicação e a argumentação tornam-se instrumentos de concreção jurídica, de manutenção da atualidade do Direito frente às mudanças no decorrer do tempo, e promoção dos princípios e valores, além de alterarem o papel do Magistrado no mundo jurídico; e, por fim, (5) ocorrem a afirmação e o delineamento de uma teoria dos direitos fundamentais que, amparada pela teoria dos princípios e dos direitos subjetivos, aproxima o Direito à moral, estabelecendo uma conexão necessária entre ambos. Passemos, pois, a uma breve análise desses aspectos teóricos, ideológicos e metodológicos, sem os quais não há que se falar em pós-positivismo.

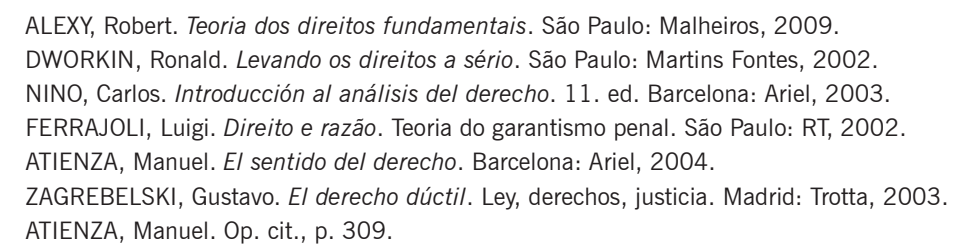




\subsection{O DIREITO SOB A NOVA PERSPECTIVA}

A inviabilidade de "[...] contentar-se com o relativismo ético subjacente ao positivismo jurídico nas suas variadas expressões, que via no Direito uma forma vazia, a qual poderia ser preenchida com qualquer conteúdo"14, implicou uma mudança na perspectiva de se considerar o ordenamento jurídico.

O Direito passa a ser visto como um sistema aberto, ao contrário daquele sistema fechado e estanque, avesso à moral e à ética, que encontrava em si próprio a razão de existência e fundamentação. Torna-se um sistema axiológico-teleológico ${ }^{15}$, muito distinto daquele sistema axiomático-dedutivo, introspectivo por natureza e acentuadamente legal. Agora, o sistema jurídico pode ser expresso como um ordenamento confeccionado pelo Estado que se encontra em constante diálogo com valores, com a ética, com a moral, isto porquanto serve como um instrumento para a realização e concreção dos ideais, anseios e afãs da sociedade, sendo legitimado, em parte, por elementos supralegais. É um meio cujo fim é a paz social, a equidade e a ordem, nunca perdendo de vista a promoção da realização do homem em todos os seus aspectos pessoais.

É axiológico porque se encontra em constante diálogo com o universo da ética e dos valores. E teleológico porquanto a sua existência está condicionada a uma finalidade, qual seja, a da promoção dos elementos constituintes daqueles universos, sobretudo da dignidade da pessoa humana, que passa a ser o eixo central de toda a envergadura jurídica.

\subsection{MudanÇa de PAPÉIS No CENárIO JuRídICO}

Ontem os Códigos; hoje as Constituições. A frase lapidada por Paulo Bonavides, ao ser agraciado com a medalha Teixeira de Freitas, em 1998, no Instituto dos Advogados Brasileiros, expressa muito bem o movimento que se deu em meados do século XX. De fato, em um universo jurídico marcado pelo civilismo e suas decorrências principais - patrimonialismo e individualismo -, consequência da avalanche liberal oitocentista, a Constituição, outrora esquecida como uma mera carta política, sem muita

14 SARMENTO, Daniel. Livres e iguais: estudos de direito constitucional. Rio de Janeiro: Lumen Juris. In: FERNANDES, Marcelo. A transcendência dos fundamentos determinantes das decisões proferidas pelo Supremo Tribunal Federal na fiscalização abstrata de constitucionalidade. Observatório da Jurisdição Constitucional, Brasília, a. 3, 2009/2010.

15 CANARIS, Claus Wilhem. Pensamento sistemático e conceito de sistema na ciência do Direito. 3. ed. Lisboa: Fundação Calouste Gulbenkian, 2004; e, também, LARENZ, Karl. Metodologia da ciência do Direito. 3. ed. Lisboa: Fundação Calouste Gulbenkian, 1997. 
efetividade normativa, a partir do pós-positivismo ganhou força e lugar no ordenamento jurídico. O Código Civil ${ }^{16}$ teve que observar a acentuada ascensão da Constituição e, por fim, dar lugar no trono da ordem jurídica ${ }^{17}$. Esta encontrou na carta de envergadura maior o meio de legitimidade, tanto moral quanto jurídica.

Ainda que, materialmente, muitas das questões tuteladas pelas normas constitucionais tenham sede no Direito Civil, a necessidade de atribuir relevância normativa e um maior resguardo de tais questões fez com que a Constituição as abraçasse, revestindo-as com a maior envergadura jurídica possível. É o caso dos direitos da personalidade e, em última instância, até da dignidade da pessoa humana.

Para ensejar essas mudanças, a unidade formadora da Carta Constitucional - e de todo o ordenamento jurídico ${ }^{18}$ - teve que passar por algumas mudanças. As normas constitucionais ganharam efetividade e passaram a estabelecer vínculo com direitos, princípios e valores.

Antes de 1948, na Europa, e de 1988, no Brasil, a Constituição era tratada apenas como uma carta política, destituída de normatividade, sendo que quem tinha real importância para o Direito era o Código Civil. Era uma lei acomodada a uma perspectiva historicista e puramente descritiva das instituições vigentes, figurando como inócua, tendo suas potencialidades como fonte de um verdadeiro Direito desprezadas ${ }^{19}$. No Brasil, a prática jurídica pós-1988 passou a incorporar a efetividade das normas constitucionais. Deu-se ao direito constitucional uma nova linguagem e um sentido normativo. Como mais uma vez assevera em bom tom o eminente Professor Luís Roberto Barroso, "a Constituição [...] adquiriu força normativa e foi

16 Ainda que, equivocadamente, fale-se que o Código Civil seja a constituição do sistema privado, não Ihes assiste razão porquanto não é admissível na atualidade a vetusta dicotomia "sistema privado" e "sistema público", sendo que o sistema jurídico é uno e não fracionado. Há, também, quem diga que o Código Civil seja a "constituição do homem comum", engano que acomete mestres da lavra do Professor Miguel Reale. A constituição do homem comum não é outra senão a própria Carta da República: não é à toa que possui 0 epíteto "cidadã". De fato, como nenhuma outra, a Constituição de 1988, reconhecendo direitos e garantias do homem, mudou o perfil do sistema jurídico nacional, tornando-o eminentemente axiológico e personalista. Além disso, no contexto do Estado Social, Estado e sociedade não se distinguem, mas se identificam, não existindo, assim, o "homem trabalhador", o "homem consumidor", o "homem proprietário" ou o "homem civil", mas somente o "homem constitucional". Ver NALIN, Pedro. Cláusula geral e segurança jurídica no Código Civil. Revista Trimestral de Direito Civil, Rio de Janeiro: Padma, v. 23, p. 60, jul./set. 2005.

17 Sabe-se que o novel Código Civil que entrou em vigor em 2003 está impregnado com cláusulas gerais. Ora, é a Constituição a referência de conexão axiológica entre o Código Civil e as cláusulas gerais. Como afirma Gustavo Tepedino, citado por Paulo Nalin, "as cláusulas gerais do novo Código Civil poderão representar uma alteração relevante no panorama do direito privado brasileiro desde que lidas e aplicadas segundo a lógica da solidariedade constitucional e da técnica interpretativa contemporânea" (Idem).

18 BOBBIO, Norberto. Teoria do ordenamento jurídico. 10. ed. Brasília: UnB, 1999. p. 51.

19 BARROSO, Luís Roberto. O direito constitucional e a efetividade de suas normas. 9. ed. Rio de Janeiro: Renovar. p. 7-8. 
alçada, ainda que tardiamente, ao centro do sistema jurídico, fundamento e filtro de toda a legislação infraconstitucional. Sua supremacia, antes formal, entrou na vida do país e das instituições" ${ }^{\prime 20}$. A Constituição, sob a óptica pós-positivista, ganha, relativamente, autonomia e existência própria, ordenando e conformando os contextos social, político, econômico e jurídico, decorrência de sua força normativa. Além disso, à Constituição foram introduzidos inúmeros princípios, os quais interagem com outros domínios científicos, culturais e sociais, promovendo a concretização de valores, objetivando a máxima impermeabilidade da ordem jurídica à injustiça.

Ademais, nesse contexto, é profícuo lembrar que, como à Constituição foi auferida normatividade, tendo sua posição no sistema jurídico transmudada, sendo a lei fundamental de toda a ordem jurídica, os mecanismos de controle de constitucionalidade tornaram-se mais rígidos, sendo sua manutenção viabilizada por Tribunais Constitucionais.

A esta reviravolta no cenário jurídico, principiada com o advento da Carta Constitucional da Alemanha, em 1949, e da Itália, em 1948, com um novo posicionamento teórico-ideológico e metodológico acerca de questões constitucionais, dá-se o epíteto de "neoconstitucionalismo". O neoconstitucionalismo é o reflexo do pós-positivismo na Constituição e na sua relação com o ordenamento jurídico. No Brasil, a Constituição de 1988 é a resultante do contexto neoconstitucionalista.

\subsection{SOBRE PRINCÍPIOS E REGRAS}

No centro das questões, sob os auspícios do pós-positivismo, está a questão acerca dos princípios, dando novos contornos principalmente à dogmática constitucional, servindo como subsídio para superar o positivismo jurídico.

Corrobora-se a concepção de que o Direito não seria somente um sistema de regras, como queriam os preceptores do juspositivismo, mas sim um sistema que conjuga, ao lado daquelas, os princípios. Ambos desempenham funções diferentes, não se podendo falar, assim, da primazia de uma norma sobre a outra.

Para essa mudança de paradigma contribuiu decisivamente os ensinamentos de Dworkin ${ }^{21}$ e, posteriormente, de Alexy ${ }^{22}$, o qual deu continuidade às teses daquele.

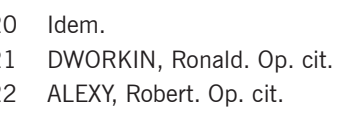


O grande trunfo daqueles insignes juristas foi formatar teorias que se baseiam não em critérios como generalidade e especialidade da norma, mas em critérios lógicos - na estrutura e na forma de aplicação ${ }^{23}$. Cabe uma brevíssima exposição das ideias por eles desenvolvidas.

Ronald Dworkin, predecessor do também eminente Jurista inglês Hebert Hart, foi o inaugurador do tema nas discussões no mundo jurídico. A grande crítica aos ensinamentos de Hart feita por Dworkin incidiu sobre a tese positivista de que o Direito seria constituído somente por regras. A ideia seria correta se não houvesse casos que fogem à normalidade da simples e mera subsunção das regras aos casos concretos: são os chamados casos difíceis ou hard cases. Eram assim denominados porque a resolução dos tais demanda a interpretação de termos vagos e ambíguos. Para os positivistas, o que marcava a decisão destes casos complexos era a discricionariedade dos Magistrados, não havendo uma regra jurídica aplicável.

Dworkin refutou essa ideia afirmando que, em casos difíceis, envolvendo direitos e obrigações, os juízes não estão revestidos sob o manto da discricionariedade, mas jungidos a parâmetros que não são regras, mas princípios e polices (metas governamentais para a melhoria de algum aspecto econômico, político ou social da comunidade ${ }^{24}$ ).

Princípios (general principles of law) seriam razões que indicam ao juiz a direção a ser tomada, mas não exigem uma única conclusão. São normas jurídicas dotadas de peso e, assim, maleabilidade, que abarcam valores fundamentais. Ao contrário das regras que são aplicadas peremptoriamente, por meio do all-or-nothing, sendo razões determinantes em face de um caso concreto, pode haver outros princípios que apontem em direção oposta, devendo o Magistrado proceder ao sopesamento dos princípios frente os fatos subjacentes. Dworkin argumenta que, enquanto as regras possuem apenas a dimensão da validade, os princípios possuem também outra dimensão, qual seja, o peso. Assim, tem prevalência em um caso específico o princípio que tiver maior peso, isto é, for mais importante.

Na mesma linha de Dworkin - o qual se bastou em delineamentos gradativos -, Robert Alexy deu contornos qualitativos à teoria dos princí$\operatorname{pios}^{25}$. Para o eminente alemão, princípios seriam mandamentos de otimização, isto é, prima facie, imporiam direitos e deveres; caso houvesse a hipótese de conflito ou colisão entre eles, aplicar-se-ia um princípio na medida

SILVA, Luis Virgílio Afonso da. O proporcional e o razoável. RT, São Paulo: RT, 798/23-50, 2002.

DWORKIN, Ronald. Op. cit., p. 22.

SILVA, Virgílio Afonso da. Princípios e regras: mitos e equívocos acerca de uma distinção. Revista LatinoAmericana de Estudos Constitucionais, 1(2003):610. 
das possibilidades fáticas ou jurídicas, podendo ter seu grau de realização variável, o que o torna qualitativamente distinto das regras, que expressam direitos e deveres definitivos, devendo ser aplicadas por inteiro, nem mais, nem menos. Importante notar, conforme ensina o Professor Virgílio Afonso da Silva, que "a realização integral de um determinado princípio pode ser - e frequentemente é - obstada pela realização de outro princípio" ${ }^{26}$. Chega-se a um resultado ótimo, dependente dos matizes do caso concreto, por meio de um sopesamento.

Talvez a discussão acerca dos princípios e a sua invariável inserção no ordenamento jurídico tenha sido a grande tônica do pós-positivismo. $\mathrm{E}$ isto porquanto os princípios abarcam noções valorativas, o que aproxima o Direito das outras esferas do conhecimento. Decerto que as inovações e mudanças que as teorias do princípio trouxeram mudanças tanto em sede prática quanto em sede metodológica.

Começando de trás para frente, com o abrigo que os princípios encontraram no ordenamento jurídico, a ciência do Direito não pode restar neutra. Ora, foi dito que o estudo dos textos legais deve sempre ser feito sob a óptica axiológica, o que, sob a lente pós-positivista, está correto. Agora, cabe descer à minúcia: o estudo dos textos legais deve sempre ser feito sob a óptica principiológica. São os princípios elementos que abarcam cargas axiológicas, éticas e morais. Caso alguma regra denote alguma mensagem que atinja seriamente algum princípio, a tal deve ser tida como inválida. Assim, o dogma positivista de neutralidade do jurista não encontra sintonia com a teoria dos princípios, com a nova face do Direito e com o manto pós-positivista.

Ademais, em plano judicante, ao outorgar aos princípios a condição de normas jurídicas, demonstra-se que o fato de os juízes se utilizarem de outros critérios, que não apenas regras, na aplicação do Direito não significa que estejam agindo discricionariamente, mas apenas aplicando elementos estruturantes do sistema jurídico, que não se confundem com seus próprios valores.

Quando se diz que um princípio faz parte do Direito, o que se pretende é que ele seja levado em conta por aquele que tem a responsabilidade de tomar a decisão. De fato, é o Magistrado que, em face dos casos que lhe são postos, avalia o peso de cada princípio colidente, de maneira que ele pode cooperar na compreensão do sentido que deve ser dado a uma determinada norma e como princípios concorrentes devem ser harmonizados.

26 Idem, p. 611 


\subsection{DeSENVOLVIMENTO JUDICIAL}

Em se tratando do desenvolvimento judicial sob a óptica pós-positivista, podemos observar novas características e redefinição de três áreas: interpretação ${ }^{27}$, aplicação e argumentação jurídica.

A interpretação e a aplicação sempre foram temas revestidos de relevância e redefinições no campo jurídico. Desde os exegéticos franceses do século XIX, interpretação e aplicação do Direito são vistos como processos distintos e separados. O Magistrado estava orientado abstratamente pela mera subsunção lógica, mecânica. Em outras palavras, a função do juiz era ditar o prescrito em lei e a ela estar invariavelmente preso. Isto era interpretar uma lei. Não é à toa que é comum dizer que o juiz era "boca da lei": não se cogitava em permitir espaço para a criação de uma solução para o caso concreto, sem contar que o dogma da completude permeava todo o pensamento jurídico. E, assim, a interpretação e a aplicação não passavam de processos mecânicos que exigiam pouca ou nenhuma participação criativa dos Magistrados. E assim foi até a metade do século XX. É claro que, no grassar dos anos e de corrente doutrinária para outra, as ideias de interpretação e de aplicação foram cambiando, ainda que apenas no campo conceitual. Interpretação passa a ser definida como a busca pelo sentido e alcance da norma jurídica. E aplicação, a consequente daquele processo no caso concreto. Texto e norma se equivaliam. Aduzia-se que o intérprete debruçava-se sobre a norma jurídica e, a partir dela, da premissa maior, passava-se aos fatos, a premissa menor. Este era o raciocínio jurídico: configurado como o processo lógico-dedutivo que, agregando ambos, norma e fato, premissa maior e premissa menor, logicamente, por meio do silogismo jurídico, resultava automaticamente na solução do caso individual e concreto. O texto legal, figurativamente, pode ser representado como uma cápsula hermética na qual o juiz se insere e ali permanece preso. Tal quadro é denominado como paradigma da aplicação ou da construção jurisprudencial.

27 Sobre as técnicas hermenêuticas engendradas na órbita constitucional, vale conferir: BARROSO, Luís Roberto. Interpretação e aplicação da Constituição. 6. ed. São Paulo: Saraiva, 2006; BARROSO, Luís Roberto; BARCELLOS, Ana Paula de. O começo da história. A nova interpretação constitucional e o papel dos princípios no Direito brasileiro. In: BARROSO, Luís Roberto (Org.). A nova interpretação constitucional: ponderação, direitos fundamentais e relações privadas. 2. ed. Rio de Janeiro: Renovar, 2006. p. $327-$ 378; SARMENTO, Daniel. A ponderação de interesses na Constituição Federal. Rio de Janeiro: Lumen Juris, 2003; BONAVIDES, Paulo. Curso de direito constitucional. 19. ed. São Paulo: Malheiros, 2006. p. 488-524; TAVARES, André Ramos. Fronteiras da hermenêutica constitucional. $1^{\text {a }}$ obra da Coleção Professor Gilmar Mendes. São Paulo: Método, 2006; COELHO, Inocêncio Mártires. Interpretação constitucional. 3. ed. São Paulo: Saraiva, 2007. p. 88-91; SILVA, Christiane Oliveira Peter da. Hermenêutica de direitos fundamentais: uma proposta constitucionalmente adequada. Brasília: Brasília Jurídica, 2005; QUEIROZ, Cristina. Interpretação constitucional e poder judicial: sobre a epistemologia da construção constitucional. Coimbra: Coimbra, 2000. Para um interessante estudo crítico sobre o tema, confira-se obra já consagrada: STRECK, Lenio Luiz. Hermenêutica jurídica e $(m)$ crise - Uma exploração hermenêutica da construção do direito. 6. ed. Porto Alegre: Livraria do Advogado, 2005. 
Não obstante as novas e diversas demandas sociais pela solução mais justa, a partir do desdobramento do Estado Social e do pós-positivismo, exigia-se do Magistrado uma postura mais eclética, mais livre e peremptória, de modo que os anseios sociais, cada vez mais novos, pudessem ser devidamente respondidos. Como afirma Amaral, apoiado em Maria José Farinas Dulce, "aqueles modelos jurídicos racionalistas da modernidade resultam insuficientes para responder muitos dos problemas que atualmente se apresentam"28. A coletividade passa a ver no Direito uma oportunidade de ver seus direitos e garantias devidamente assegurados. Nesse diapasão, o juiz não pode mais estar preso por uma camisa de força teorética. A função criadora é fundamental para a atividade judicante, sendo que a leitura do texto legal realiza-se por meio das lentes dos princípios e das regras constitucionais. O texto é o alvo de interpretação, e o resultado é a norma jurídica, concreta e individual. Não se interpreta a norma, mas sim o dispositivo legal. Ademais, interpretação e aplicação tornam-se fatores de uma mesma equação: não há que separá-los. Ambos estão orientados pelo objetivo prático da realização do Direito. Com essa nova perspectiva interpretacional, é possível pôr em prática os novos ditames jurídicos constituídos de importância crescente dos valores e dos princípios jurídicos e também proporcionar ao texto legal uma maior elasticidade temporal. É o paradigma da aplicação; o novo modelo de interpretação jurídica. Como afirma o eminente Civilista Francisco Amaral,

[...] com esse espírito e já na segunda metade do século XX, a interpretação jurídica passa a considerar-se o maior problema, o mais vivo da atual problemática filosófico-jurídica, sugerindo-se a passagem do modelo tradicional normativista, ou da exegese, para um novo modelo hermenêutico de tipo axiológico, ou jurisprudencialista [...]. ${ }^{29}$

Essa hermenêutica diferenciada vai suscitar, portanto, toda uma gama de novas discussões na arena da interpretação constitucional: concreção, colisão de princípios constitucionais, ponderação, argumentação, etc.

Last but not least, a teoria da argumentação tem um papel de destaque no pós-positivismo, sendo ela a arma para que a Justiça, a equidade e a segurança jurídica, ainda que por vezes conflitantes, sejam preservadas.

É imprescindível asseverar que o Magistrado deve estar jungido aos ditames dos enunciados legais, não podendo ignorá-los na resolução dos

28 AMARAL, Francisco. O Código Civil brasileiro e o problema metodológico de sua realização. Do paradigma da aplicação ao paradigma judicativo-decisório. Revista Brasileira de Direito Comparado, Rio de Janeiro: Instituto de Direito Comparado Luso-Brasileiro, n. 28, p. 53, $1^{\circ}$ sem. 2005. 
casos concretos. Todavia, a necessidade suprema de concretizar, realizar e operabilizar o dever-ser axiológico consubstanciado na própria ordem jurídica por meio da Constituição é motivo suficiente para que o juiz afaste as disposições legais a partir das peculiaridades e diversas matizes do caso que se lhe apresenta.

Para realizar tal divergência que, para muitos, seria algo absurdo, que fere e conspurca todo o ordenamento jurídico, o Magistrado tem em mãos a arma da argumentação. É a partir da teoria argumentativa que o juiz pode afastar a lei para realizar e concretizar o dever-ser axiológico no caso concreto, evocando razões robustas, revestidas de relevância para a unidade e organicidade da ordem social e jurídica, para que haja solução justa.

Não podemos ignorar a lei. Contudo, a lei não é suficiente como argumento decisório. Daí a importância do discurso jurídico e da argumentação. A possibilidade de o juiz afastar a lei, constituindo cláusula de exceção, advém da racionalidade argumentativa.

É preciso que o Magistrado observe os comandos legais, mas, também, é seu dever trabalhá-los - e aí entra o papel da argumentação - para produzir um resultado justo. O juiz pode deixar de aplicar qualquer lei se, e somente se, houver um argumento forte o suficiente para justificar o afastamento da lei - a não aplicação da norma. Para tanto, deve manter atenção ao contexto fático, argumentar com racionalidade e trazer fundamentações, isto é, razões que motivam sua decisão.

É com o desenvolvimento judicial que podemos partir para a prática: sair do campo da retórica e do nível do discurso e das ideias e concretizar as inovações e propostas pós-positivistas. Efetua-se a promoção dos princípios, dos direitos fundamentais e de valores em cada caso concreto. Assim, o desenvolvimento judicial, estreitamente vinculado às teorias e à ideologia dominante do Direito, é o meio de concretização do Direito. Passa-se da teoria e adentra-se o campo da atividade. Nisso resta a importância do desenvolvimento judicial nesses novos tempos.

Nunca é demais lembrar: o Direito só tem sentido quando voltado para a prática.

\subsection{Direitos Fundamentals: a GRANDE PERSONAGeM DO Pós-POSIIIIIISMO}

Não se pode olvidar que o pós-positivismo renovou o vigor na discussão acadêmica e nos Tribunais de um tema revestido de importância ímpar para o Direito e para a manutenção da ordem e na limitação da atuação estatal: os direitos fundamentais. 
Como ensina o Ministro Gilmar Mendes,

os direitos fundamentais são, a um só tempo, direitos subjetivos e elementos fundamentais da ordem constitucional objetiva. Enquanto direitos subjetivos, os direitos fundamentais outorgam aos titulares a possibilidade de impor os seus interesses em face dos órgãos obrigados. Na sua dimensão como elemento fundamental da ordem constitucional objetiva, os direitos fundamentais - tanto aqueles que não asseguram, primariamente, um direito subjetivo, quanto aqueloutros, concebidos como garantias individuais - formam a base do ordenamento jurídico de um Estado de Direito democrático [...].

Posteriormente, define os direitos fundamentais como sendo "[...] direitos de defesa (Abwehrrechte), destinados a proteger determinadas posições subjetivas contra a intervenção do Poder Público [...]"30.

Não é de agora que a discussão acerca dos direitos fundamentais esteve presente no âmbito jurídico e político. De fato, o Estado liberal, nascido no limiar do século XIX, esteve compromissado em assegurar direitos políticos e civis, direitos fundamentais de primeira dimensão. Com o posterior Estado social, os direitos fundamentais de segunda e terceira dimensão vieram a lume. Trata-se dos direitos sociais e do direito ao desenvolvimento. Paulo Bonavides denominou esse perfil histórico de Estado como "o Estado constitucional dos direitos fundamentais" ${ }^{\prime \prime 2}$. E foi assim porque, como assevera o eminente publicista, "[...] a teoria da norma constitucional passou a ter [...] a legitimidade por fundamento. A legitimidade é o direito fundamental, o direito fundamental é o princípio, e o princípio é a Constituição na essência $[\ldots]^{\prime \prime 2}$.

A historiografia estatal nos ensina que o Estado social surgiu a partir da década de 1920 do século passado, mas ganhou força logo após a Segunda Grande Guerra, coincidindo sua existência com o pós-positivismo. Por conseguinte, podemos concluir que o Estado, mormente a partir da segunda metade do século $X X$, encontrou fundamento, em última instância, nos direitos fundamentais. Tal importância levou juristas revestidos pelo manto das inovações teóricas e ideológicas pós-positivistas a desenvolverem teorias acerca do direito fundamental, o que possibilitou avanços importantes na resguarda da dignidade do homem e suas decorrências, na liberdade, na igualdade, tanto na área doutrinária quanto na judicante.

30 MENDES, Gilmar. Os direitos fundamentais e seus múltiplos significados na ordem constitucional. Revista Diálogo Jurídico, Salvador, n. 10, p. 2, jan. 2002.

31 BONAVIDES, Paulo. Teoria do Estado. 7. ed. São Paulo: Martins Fontes, 2008. p. 46.

32 Idem. 
O grande inaugurador de uma teoria mais estrutural e incisiva acerca dos direitos fundamentais foi Robert Alexy. Em sua inovadora obra, Teoria dos direitos fundamentais, o eminente jurista demonstra que a positivação dos direitos fundamentais, aos quais todos os Poderes estatais estão vinculados, significa uma abertura do sistema jurídico diante da moral, abertura que é razoável e que pode ser levada a cabo por meios racionais.

Daí se dizer que a presença de normas de direitos fundamentais nos sistemas jurídicos tem origem na concepção pós-positivista de intrínseca relação entre Direito e moral. De fato, as normas de direitos fundamentais são caracterizadas como a tradução jurídica dos valores morais de uma comunidade em determinado momento histórico ${ }^{33}$. Assim, a importância dos direitos fundamentais gravita em torno do seguinte corolário: devido à presença dessas normas, os ordenamentos jurídicos deixam-se impregnar por conteúdos morais. Assim, situam-se no ponto de interseção entre Direito e moral, implicando uma nova abordagem interpretativa e argumentativa, que é simultaneamente moral e jurídica ${ }^{34}$, além de uma necessária legitimidade axiológica do sistema jurídico.

\subsection{RefLEXÕES}

Decerto que esta nomenclatura - pós-positivismo - é dada ao período vivenciado no pós-guerra, perdurando até os dias de hoje. Com ela, avançaram-se as contribuições teórica e metodológicas para o estudo do Direito, como já visto. E isso é inquestionável. A face do Direito mudou completamente: iniciou o século XX vinculado à onda liberal da centúria passada, para seguir o fluxo social e humano no novo século. Do paradigma da legalidade para o paradigma da axiologia, muita água correu.

Juristas que, indo além da mera mecanicidade e entorpecente legalidade que impregnavam o Direito antes da década de 1950, identificaram uma revigorada face do direito positivo, o que refletiu na ciência jurídica: uma face axiológica, uma face teleológica, uma face aberta, na qual o Direito está em constante comunicação com a moral e com princípios e valores. Mostrou-se que o estudo do direito positivo não deve ser feito com neutralidade por meio de juízos de fato, e não de valor. Trouxeram à baila novos aspectos do Direito que devem ser estudados não com a mesma lente científica empregada nas ciências exatas e biológicas.

33 VALLE, André Rufino. Aspectos do neoconstitucionalismo. Revista Brasileira de Direito Constitucional, n. 9, p. 72, jan./jul. 2007.

34 Idem. 
Tal posicionamento se erigiu exatamente no ínterim entre 1947 e 1948, no decorrer do julgamento de Nuremberg, no qual se fixou, assim penso, uma nova definição para o direito estatal. A partir de então, a busca por uma definição e caracterização do Direito deve passar obrigatoriamente pelo crivo da moral crítica, que leva, inevitavelmente, à moral legalizada. Se uma norma veicular um conteúdo que vá de encontro aos valores consagrados pela "audiência universal", ela não deve ser considerada como válida, não pertencendo ao ordenamento jurídico. E, por isso, não tem imperatividade nem obrigatoriedade.

Ademais, a lei não vale por ser lei, isto é, a concepção de validade em questão, a partir do fracasso positivista, não se basta na formalidade, deixando o povo e os juristas à mercê de leis arbitrárias, cruéis e criminosas ${ }^{35}$. Tais leis carecerão de validade material, o povo não lhes deverá obediência e os juristas deverão ser os primeiros a recusar-lhes o caráter de jurídicas, o que nos leva à impossibilidade de posição neutra do cientista jurídico frente ao seu objeto, o texto legal.

É importante que se observe que o Direito, sendo um resultado histórico-cultural da vida de certa sociedade, deve estar voltado para os interesses dela, interesses da coletividade. E, nos dias de hoje, não se pode compreender, ou dar lugar, a um Direito que não um sistema aberto de princípios e regras. A sociedade rejeitará, e rejeita, qualquer Direito que se pareça com aquele antiquado e ultrapassado, marcadamente normativista. Diferentemente do que se pensava sob o ângulo do positivismo jurídico, não se deve dizer: tudo o que for útil ao povo é direito; mas, pelo contrário: só o que for direito será útil e proveitoso para o povo. Assim, arbítrio, violação de tratados, ilegalidade, o capricho do déspota, a pena decretada sem lei ou sentença anterior, um "Estado-contra-o-direito" nunca poderão ser configurados a partir do legítimo Direito. Radbruch, eminente jurista alemão, um dos precursores de concepções pós-positivistas, ensina-nos que "Direito quer dizer o mesmo que vontade e desejo de justiça. Justiça, porém, significa: julgar sem consideração de pessoas; medir a todos pelo mesmo metro"36.

As demandas da coletividade de hoje não são supridas pelo Direito oitocentista e nunca poderão ser. Hoje, está-se precisando de um Direito, como já dito à exaustão, aberto a valores, flexível aos ditames ético-sociais, tendo como fim a justiça e o bem comum.

35 RADBRUCH, Gustav. Filosofia do direito. São Paulo: Martins Fontes, 2004. p. 416.

36 Idem. 
Assim, a necessidade de se deixarem de lado teorias e teses revestidas por exacerbada cientificidade não é mero capricho doutrinário. É, sobretudo, um anseio social.

O pensamento que se tem que ressuscitar e ser renovado na mente daqueles que formam a seleta comunidade jurídica, composta tanto por juristas quanto por operadores, é que o positivismo jurídico, tanto na perspectiva teórica quanto na ideológica e até mesmo na metodológica, está superado $^{37}$. Não há mais como reduzir tudo o que pertence ao mundo jurídico - os direitos e a justiça - ao disposto pela lei. E isso porquanto os fatores decisivos para seu gênese e consolidação como ciência da legislação positiva não estão mais em vigor.

É insustentável, nos tempos atuais, aquela pretensão mais formalista e lógica de erigir uma teoria pura, fundada na estreita vinculação entre o Estado, o Direito e a lei, e que alija de seu bojo qualquer conteúdo axiológico. A realidade jurídica do denominado Estado constitucional é incompatível com aquela vetusta corrente jusfilosófica. De fato, o Direito está impregnado de preceitos normativos que assumem a estrutura de princípios e valores, que são de natureza moral ou que requerem do intérprete o recurso à moral para definir seu significado e conteúdo ${ }^{38}$.

Ademais, o Estado constitucional é marcado pela presença em peso de normas constitucionais que dialogam constantemente com direitos fundamentais e preceitos de justiça material. Também, como já visto, as normas infraconstitucionais devem se conformar ao conteúdo substancial dos dispositivos constitucionais e dos princípios suprajurídicos. Com efeito, tornam-se inadequadas as teses positivistas da rígida separação entre Direito e moral e da unicidade do critério formal de validade das normas ${ }^{39}$, traduzido na norma fundamental de Kelsen e na regra de reconhecimento de Hart. Na linguagem de Kelsen, os sistemas jurídicos são simultaneamente dinâmicos e estáticos, na medida em que comportam critérios formais e materiais de identificação do conteúdo do Direito. Em outras palavras, a validade das normas é constituída tanto pelo aspecto formal (dependente de sua origem em um órgão competente, segundo as regras procedimentais previstas na Constituição) quanto pelo aspecto material (correspondência de seu conteúdo material com os valores ou com o sistema de moralidade que con-

\footnotetext{
Ver supra 1.3.

VALLE, André Rufino. Op. cit., p. 72.

39 Idem.
} 
forma todo o ordenamento jurídico ${ }^{40}$. Portanto, as teorias pós-positivistas - como as de Dworkin e as de Alexy -, que relativizam a separação entre Direito e moral, admitindo critérios materiais de validade das normas, estão mais bem adaptadas para descrever o sistema jurídico dos Estados constitucionais.

\section{PARTE II: A CRISE DA LEGALIDADE" ${ }^{41}$}

\subsection{A CRISE}

"As leis não bastam. Os lírios não nascem das leis". Esta frase de Carlos Drummond de Andrade é sinalizadora. Leva-nos à reflexão, sejamos juristas ou não...

Ao contrário do que muita gente pensa, as ideias e teses advindas do império do pós-positivismo não são contrárias às leis. Uma não exclui a outra. Não se tenciona diminuir a lei, ignorando seus desígnios, por meio de uma retórica axiológica muitas vezes vazia de sentido e ensejadora de exagerada discricionariedade e arbítrio judicial.

É por demais compreensivo que se olvide o caráter legal do Direito. Como dito, a humanidade ainda não se esqueceu da catástrofe humana decorrida de uma ideologia positivista que não admitia a desobediência à lei enquanto tal ${ }^{42} \mathrm{e}$, por isso mesmo, não era tolerável que se questionasse o comando da lei, seu conteúdo.

De fato, a partir de então, abriu-se caminho para uma teoria do Direito voltada menos ao caráter científico e mais ao caráter axiológico, o que é, em tese, positivo para o Estado, para a sociedade e para o próprio Direito.

Com o passar dos anos, contudo, essa ideia foi sendo distorcida, servindo, erroneamente, como justificativa para uma antilegalidade. Para fundamentar uma falta de cultura da legalidade ${ }^{43}$, esquece-se de que o pós-

40 "Por exemplo, a ninguém soa estranho que o princípio ou valor da dignidade humana seja uma condição substancial de validade de todas as normas do sistema jurídico." (Idem, p. 72)

41 Ao se referir à legalidade, tenciona-se ao seu significado mais amplo.

42 "[...] na definição dada pelo positivismo jurídico não está compreendido o requisito da justiça, mas somente o de validade. Ou, se se prefere [...], poderíamos dizer que este considera a lei justa pelo único fato de ser válida [...]." (BOBBIO, Norberto. O positivismo jurídico. Lições de filosofia do direito. São Paulo: Ícone, 1995. p. 225)

43 PELUZO, Cezar. Há completo desprezo pela legalidade no Brasil. Conjur, Brasília, [s.d.]. Entrevista concedida a Rodrigo Haidar pelo Ministro do Supremo Tribunal Federal Cezar Peluzo. Disponível em: <http://www. conjur.com.br/2009-fev-01/entrevista-cezar-peluso-ministro-supremo-tribunal-federal>. Acesso em: 10 jan. 2010. 
-positivismo não subjulga por completo as proposições juspositivistas, ainda primando pela certeza e previsibilidade, como visto anteriormente ${ }^{44}$.

Critica-se, sim, o fetiche pela lei, uma das características do positivismo jurídico. Não se deve misturar as coisas. Enquanto que a legalidade exacerbada e obsessiva conduz ao formalismo e à proximidade com a injustiça, a devida legalidade, temperada, mas necessária, conduz à ordem e à segurança.

O Direito é um sistema, dotado de organicidade, de ordem e de unidade, revestido com o manto principiológico. Todavia, não se pode esquecer que as regras ${ }^{45}$ fazem parte deste sistema. Não se pode, de jeito algum, sob o risco da perda da segurança jurídica, esquecer que as normas jurídicas não são apenas princípios, mas também regras.

Ademais, cumpre salientar que o próprio Estado Constitucional de Direito traz, em seu bojo, a ideia de supremacia e primazia do Direito estatal - expressão da vontade da coletividade. Ignorar a lei é mais que um erro ou um defeito decorrente de uma falta de cultura legal: é um atentado contra os fundamentos do Estado contemporâneo.

Como anteriormente dito, o que se tenta, a partir da segunda metade do século XX, é uma concordância entre a Justiça e a segurança jurídica, tendo como base a dignidade da pessoa humana.

Sob esse aspecto, temos que, no momento de interpretação/aplicação do Direito, o Magistrado não deve esquecer aqueles dois valores caríssimos à ordem jurídica, sendo que a dignidade do homem situa-se no centro de tal. Ademais, os legisladores também não podem, de maneira nenhuma, criar normas gerais e abstratas lesivas aos direitos da personalidade, interferindo negativamente na esfera da integridade moral, física e intelectual.

Todavia, ocorre que, devido àquela generalidade e abstração, as leis não comportam todos os elementos fáticos dos casos concretos que são apresentados aos juízes. Esses elementos, direta ou indiretamente ligados a uma daquelas esferas dos direitos personalíssimos, são muitas vezes decisivos, oferecendo razão forte o suficiente para que aquela regra não seja aplicada.

Assim, o Magistrado pode se utilizar da arma da argumentação, racionalmente prática por natureza, para afastar a lei.

44 Ver supra 1.2.

45 O vocábulo "regra", aqui, é usado como sinônimo de "lei". Não é ignorado o significado do referido vocábulo, mas, para o presente artigo, é considerado como elemento jurídico preceptor de comandos definitivos - lei lato sensu. Assim, à "lei" e à "regra" (esta no sentido dado por Alexy) são atribuídos significados semelhantes. 
Entretanto, este processo não deve ser utilizado em todos os casos, levando a uma banalização da lei. Pelo contrário, na grande maioria das vezes, deve o Magistrado estar submetido ao império do Direito.

A profícua e correta aplicação da teoria da argumentação racional depende daquelas robustas e relevantes razões decorrentes do caso concreto; razões decorrentes de um atentado à dignidade humana, caso a regra seja aplicada.

A afastabilidade da lei é revestida de caráter subsidiário. Constitui a exceção. Não se deve, portanto, ignorar as regras sob qualquer pretexto fático ou filosófico que não tenha devida relevância e expressão para o bem-estar da coletividade.

O Magistrado, hodiernamente, deve estar, sim, jungido à lei. E o pós-positivismo não engendra pensamento contrário. O que não se admite, e foi isso que o pós-positivismo tencionou superar, é a confusão entre lei e Direito.

Podemos concluir asseverando que a falta de esmero pela legalidade é uma conspícua afronta contra os ditames do novo Direito, surgido dos monturos da Segunda Grande Guerra, sob a égide do pós-positivismo, e contra o próprio sistema jurídico.

Também é necessária uma ressalva: as regras processuais e as regras constitucionais não devem ser afastadas sob nenhuma hipótese. Grande parte das regras constitucionais e das regras processuais são regras de introdução e de inferência do sistema jurídico. Desobedecer-lhas é viciar a ordem jurídica, atingindo os efeitos pretendidos pelo sistema e indo de encontro às características inerentes ao Direito, ensejando uma situação de total desordem e insegurança jurídica - eficácia sistêmica reversa.

Ademais, a relevância da Constituição é tamanha sobre as normas infraconstitucionais que a interpretação desta se dá sob as lentes constitucionais e não o contrário.

\section{JURISPRUDÊNCIA}

Caso recente e notório de afastabilidade legal e utilização da teoria da argumentação foi o Recurso Especial no 1008.398, julgado pela Terceira Turma do Superior Tribunal de Justiça, tendo como Relatora a Ministra Nancy Andrighi.

Nas palavras da Ministra, em seu belíssimo voto: "Cinge-se a lide a analisar a possibilidade de alteração e retificação do assento de nascimento 
do recorrente, a fim de obter a modificação de seu prenome, de Clauderson para Patrícia, bem como a indicação de sexo para 'feminino' [...]".

No caso, sem descer à minúcia, o recorrente requeria o provimento ao recurso especial, julgando, assim, procedente sua pretensão de alteração e retificação do prenome para um feminino, assim como a mudança de sexo, ainda que a regra seja a da imutabilidade do nome, prenome, sexo, etc., de acordo com a Lei no 6.015/1973. Também de acordo com esta lei, as possibilidades de alteração de registro previstas são restritivas e excepcionais, a fim de que reste preservado o princípio da segurança jurídica.

Assim, para o Direito posto, a intenção do recorrente é inviável. De fato, o Ministério Público do Estado de São Paulo, que opinou pelo indeferimento da pretensão inicial, argumentou que "a hipótese em tela não se insere $[s i c]$ nas exceções de retificação previstas no parágrafo único do mencionado art. 58 da Lei no 6.015/1973 (fl. 62)"446.

Da mesma forma pensou o col. Tribunal de Justiça de São Paulo, que deu provimento, por maioria, à apelação interposta pelo Ministério Público do Estado de São Paulo, a fim de reformar a sentença, tendo em vista que,

[...] em linha de registro civil, prevalece a regra geral da imutabilidade dos dados, nome, prenome, sexo, filiação, etc. Há, portanto, um interesse público de manutenção da veracidade dos registros, de modo que a afirmação dos sexos (masculino ou feminino) não diz com a aparência, mas com a realidade espelhada no nascimento, que não pode ser alterada artificialmente. $(\text { fl. 146) })^{47}$

No caso, alega-se ofensa aos arts. $4^{\circ}$ e $5^{\circ}$ da LICC; 55,58 e 109 da Lei no 6.015/1973; 11, 13, 16, 17, 19, 20 e 21 do CC/2002; além de dissídio jurisprudencial.

Ora, lançando mão do processo argumentativo, o qual encontrou na nova postura do Direito subsídios e razões subjacentes à conjuntura fática, a eminente Ministra afastou as regras que regulam o registro de pessoa natural e concedeu a possibilidade de mudança de prenome de transexual. Segue a ementa.

DIREITO CIVIL - RECURSO ESPECIAL - TRANSEXUAL SUBMETIDO À CIRURGIA DE REDESIGNAÇÃO SEXUAL - ALTERAÇÃO DO PRENOME E

46 Brasil. Superior Tribunal de Justiça, Recebimento de recurso extraordinário, Recurso Extraordinário $\mathrm{n}^{\circ}$ 1008.398, Clauderson de Paula Viana e Ministério Público Federal, Relatora: Ministra Nancy Andrighi, Brasília, 15 de outubro de 2009. Disponível em: <https://ww2.stj.jus.br/revistaeletronica/Default. asp? registro $=200702733605 \& d t$ publicacao=18/11/2009 > . Acesso em: 17 jan. 2010.

47 Idem. 


\section{DESIGNATIVO DE SEXO - PRINCÍPIO DA DIGNIDADE DA PESSOA HU- MANA}

Sob a perspectiva dos princípios da Bioética - de beneficência, autonomia e justiça -, a dignidade da pessoa humana deve ser resguardada, em um âmbito de tolerância, para que a mitigação do sofrimento humano possa ser o sustentáculo de decisões judiciais, no sentido de salvaguardar o bem supremo e o foco principal do Direito: o ser humano em sua integridade física, psicológica, socioambiental e ético-espiritual.

A afirmação da identidade sexual, compreendida pela identidade humana, encerra a realização da dignidade, no que tange à possibilidade de expressar todos os atributos e características do gênero imanente a cada pessoa. Para o transexual, ter uma vida digna importa em ver reconhecida a sua identidade sexual, sob a ótica psicossocial, a refletir a verdade real por ele vivenciada e que se reflete na sociedade.

A falta de fôlego do Direito em acompanhar o fato social exige, pois, a invocação dos princípios que funcionam como fontes de oxigenação do ordenamento jurídico, marcadamente a dignidade da pessoa humana - cláusula geral que permite a tutela integral e unitária da pessoa, na solução das questões de interesse existencial humano.

Em última análise, afirmar a dignidade humana significa para cada um manifestar sua verdadeira identidade, o que inclui o reconhecimento da real identidade sexual, em respeito à pessoa humana como valor absoluto.

[...].

Conservar o "sexo masculino" no assento de nascimento do recorrente, em favor da realidade biológica e em detrimento das realidades psicológica e social, bem como morfológica, pois a aparência do transexual redesignado, em tudo se assemelha ao sexo feminino, equivaleria a manter o recorrente em estado de anomalia, deixando de reconhecer seu direito de viver dignamente.

\section{[...].}

Vetar a alteração do prenome do transexual redesignado corresponderia a mantê-lo em uma insustentável posição de angústia, incerteza e conflitos, que inegavelmente atinge a dignidade da pessoa humana assegurada pela Constituição Federal. No caso, a possibilidade de uma vida digna para o recorrente depende da alteração solicitada. $E$, tendo em vista que o autor vem utilizando o prenome feminino constante da inicial para se identificar, razoável a sua adoção no assento de nascimento, seguido do sobrenome familiar, conforme dispõe o art. 58 da Lei no 6.015/1973.

Deve, pois, ser facilitada a alteração do estado sexual, de quem já enfrentou tantas dificuldades ao longo da vida, vencendo-se a barreira do preconceito e da intolerância. O Direito não pode fechar os olhos para a realidade social 
estabelecida, notadamente no que concerne à identidade sexual, cuja realização afeta o mais íntimo aspecto da vida privada da pessoa. E a alteração do designativo de sexo, no registro civil, bem como do prenome do operado, é tão importante quanto a adequação cirúrgica, porquanto é desta um desdobramento, uma decorrência lógica que o Direito deve assegurar.

Assegurar ao transexual o exercício pleno de sua verdadeira identidade sexual consolida, sobretudo o princípio constitucional da dignidade da pessoa humana, cuja tutela consiste em promover o desenvolvimento do ser humano sob todos os aspectos, garantindo que ele não seja desrespeitado tampouco violentado em sua integridade psicofísica. Poderá, dessa forma, o redesignado exercer, em amplitude, seus direitos civis, sem restrições de cunho discriminatório ou de intolerância, alçando sua autonomia privada em patamar de igualdade para com os demais integrantes da vida civil. A liberdade se refletirá na seara doméstica, profissional e social do recorrente, que terá, após longos anos de sofrimentos, constrangimentos, frustrações e dissabores, enfim, uma vida plena e digna.

De posicionamentos herméticos, no sentido de não se tolerar "imperfeições" como a esterilidade ou uma genitália que não se conforma exatamente com os referenciais científicos, e, consequentemente, negar a pretensão do transexual de ter alterado o designativo de sexo e nome, subjaz o perigo de estímulo a uma nova prática de eugenia social, objeto de combate da Bioética, que deve ser igualmente combatida pelo Direito, não se olvidando os horrores provocados pelo holocausto no século passado. Recurso especial provido. (STJ, REsp 1008398/SP, (2007/0273360-5), 3aㅡ T., Rel ${ }^{\underline{a}}$ Min. Nancy Andrighi, DJe 18.11.2009)

Desta já histórica decisão do STJ podemos extrair algumas lições que fundamentam as ideias expostas neste artigo. A título de revisão, vejamos.

1) O Direito já não é mais visto como um sistema de regras, mas a conjugação destas com os princípios, os quais detêm o status de norma jurídica, expressando sempre um valor caro à sociedade que regula. A Ministra resolveu o caso utilizando-se não de regras, mas de princípios - no caso, o princípio da dignidade humana.

$2^{\circ}$ ) O Direito não pode ser visto pela óptica normativista, vinculada ao Estado liberal, na qual o juiz deve partir da norma para posteriormente observar o caso concreto, tornando a aplicação do Direito uma operação mecânica. No caso, a eminente Ministra estudou, em primeiro lugar, o plano fático e todas as suas particularidades para depois partir para o ordenamento jurídico.

3º) O Direito deve estar em consonância e em constate diálogo com os ditames axiológicos postos pela sociedade. Aqui, o signo "Di- 
reito" tanto designa "ciência aplicada" quanto "sistema normativo". Caso a Ministra fosse analisar somente o Direito em si, alijando ideias sociológicas e filosóficas, o recurso seria desprovido.

$\left.4^{\circ}\right)$ O fundamento do Direito deixou de ser a norma para ser o homem.

5) A teoria da argumentação é de importância ímpar na concretização do Direito. Utilizando-se de argumentos universalmente aceitos, a Ministra deixou de aplicar as normas extraídas da Lei no 6.015 para, a partir do princípio da dignidade humana, decidir favoravelmente o caso. Para tanto, encontrou no quadro fático razões robustas, suficientes para que se procedesse ao afastamento.

\section{4 À GUISA DE CONCLUSÃO: UM ITINERÁRIO SEM VOLTA}

Parece ser por demais ousado dissertar acerca de dois temas que, em um primeiro momento e para os mais desavisados, são extremamente paradoxais. E aceitá-los, defendendo-os, beiraria o paradoxo e, o que é pior, a incoerência. Entretanto, ao refletir sobre ambos os temas, intercalando-os, mesclando-os e comparando-os, tudo se mostra claro e coerente.

O que se colimou esclarecer foi que a aparente tensão e a incompatibilidade entre a legalidade e as ideias pós-positivistas são, em parte, infundadas. Deve ser rememorado que houve uma mudança no prisma pelo qual se observam as situações jurídicas e o próprio direito positivo. Antes, decorrentes do liberalismo oitocentista, os casos deviam ser passados pelo crivo maior e inexorável da lei, a qual impera no ordenamento jurídico. Agora, é a Constituição a lente através a qual devem ser observados os fatos e o sistema jurídico, o que implica uma mudança substancial: do princípio da legalidade, derivado da concepção estatalista do direito de antes, hoje há a supremacia da Constituição e seus reflexos jurídicos, políticos, ideológicos e axiológicos conformadores do direito positivo.

Tal mudança de óptica se impõe inevitável. A ciência jurídica entrou por um caminho que não há mão dupla. No passado, estava a rigidez lógico-normativista; no presente, a égide axiológica neoconstitucionalista; o futuro está intacto. O que podemos fazer são conjecturas, previsões próximas da probabilidade, mas nunca a exatidão.

Talvez nunca cheguemos à unanimidade e à harmonia entre os participantes do jogo jurídico. Talvez daqui a 80 anos ainda haja quem diga 
que o Direito e a moral são esferas completamente distintas e bastantes em si mesmas. Naqueles tempos, talvez ainda haja Magistrados que fechem os olhos para os fatos sociais e para os valores que conformam a sociedade. Talvez a extrema legalidade ainda seja aceita e propagada nas academias. Por outro lado, talvez a lei, nos próximos 80 anos que virão, seja cada vez mais ignorada sem razão alguma senão a falta de prudência. Talvez a crise de legalidade não tome outro caminho senão o completo e total desprezo pelas regras que ordenam a sociedade. Talvez a compreensão acerca do Direito e suas particularidades ainda estejam obscurecidas pela falta de conhecimento de suas características principais. Talvez...

Não sabemos o que nos guarda o futuro que se aproxima em alta velocidade e bate à nossa porta. Nem nos cabe saber os mistérios que estão a nos cercar. Tudo o que podemos fazer é observar o que temos em mãos: em uma, o passado e todas as lições que podemos tirar de nossas atitudes e das atitudes daqueles que moldaram o conhecimento que temos; na outra, o presente, com a esperança e a fé que nos alimentam a continuarmos o itinerário sem volta: a vida. Com as lições do passado e as motivações do presente, podemos ter a certeza de que não importa o que nos espera no futuro, estamos no caminho certo.

\section{REFERÊNCIAS}

ALEXY, Robert. Teoria dos direitos fundamentais. 1. ed. São Paulo: Malheiros, 2009.

AMARAL, Francisco. O Código Civil brasileiro e o problema metodológico de sua realização. Do paradigma da aplicação ao paradigma judicativo-decisório. Revista Brasileira de Direito Comparado, Rio de Janeiro: Instituto de Direito Comparado Luso-Brasileiro, n. 28, p. 51-80, 1ํㅗ sem. 2005.

BARROSO, Luis Roberto. A reconstrução democrática do Direito Público no Brasil. Introdução. Rio de Janeiro/São Paulo/Recife: Renovar, 2007.

. O direito constitucional e a efetividade de suas normas. 9. ed. Rio de Janeiro: Renovar, 2009.

BOBBIO, Norberto. O positivismo jurídico. Lições de filosofia do direito. São Paulo: Ícone, 1995. Teoria do ordenamento jurídico. 10. ed. Brasília: UnB, 1999.

BONAVIDES, Paulo. Teoria do Estado. São Paulo: Malheiros, 2008.

CALSAMIGLIA, Albert. Postpositivismo. DOXA - Cuadernos de Filosofía del Derecho, v. 21-I, 1998. 
CANARIS, Claus Wilhem. Pensamento sistemático e conceito de sistema na ciência do Direito. 3. ed. Lisboa: Fundação Calouste Gulbenkian, 2004.

DWORKIN, Ronald. Levando os direitos a sério. São Paulo: Martins Fontes, 2003.

FERNANDES, Marcelo. A transcendência dos fundamentos determinantes das decisões proferidas pelo Supremo Tribunal Federal na fiscalização abstrata de constitucionalidade. Observatório da Jurisdição Constitucional, Brasília, a. 3, 2009/2010.

FERRAJOLI, Luigi. Direito e razão. Teoria do garantismo penal. São Paulo: RT, 2002.

KELSEN, Hans. Teoria pura do direito. 6. ed. São Paulo: Martins Fontes, 2000.

LARENZ, Karl. Metodologia da ciência do Direito. 3. ed. Lisboa: Fundação

Calouste Gulbenkian, 1997.

MENDES, Gilmar. Os direitos fundamentais e seus múltiplos significados na ordem constitucional. Revista Diálogo Jurídico, Salvador, n. 10, jan. 2002.

NALIN, Pedro. Cláusula geral e segurança jurídica no Código Civil. Revista Trimestral de Direito Civil, Rio de Janeiro: Padma, v. 23, p. 60, jul./set. 2005.

NINO, Carlos. Introducción al análisis del derecho. 11. ed. Barcelona: Ariel, 2003.

RADBRUCH, Gustav. Filosofia do direito. São Paulo: Martins Fontes, 2004.

REALE, Miguel. Lições preliminares de direito. 27. ed. São Paulo: Saraiva, 2006.

SILVA, Luis Virgílio Afonso da. O proporcional e o razoável. RT, São Paulo: RT, 798/23-50, 2002.

. Princípios e regras: mitos e equívocos acerca de uma distinção. Revista Latino-Americana de Estudos Constitucionais, 1(2003).

VALLE, André Rufino. Aspectos do neoconstitucionalismo. Revista Brasileira de Direito Constitucional, n. 9, p. 72, jan./jul. 2007.

ZAGREBELSKI, Gustavo. El derecho dúctil. Ley, derechos, justicia. Madrid: Trotta, 2003. 